\title{
Melon Resistance to Cucurbit yellow stunting disorder virus Is Characterized by Reduced Virus Accumulation
}

\author{
Cristina F. Marco, Juan M. Aguilar, Jesús Abad, María Luisa Gómez-Guillamón, and Miguel A. Aranda
}

\begin{abstract}
First, second, and fourth authors: Estación Experimental "La Mayora," Consejo Superior de Investigaciones Científicas, 29750 AlgarroboCosta, Málaga, Spain; third author: Seminis Vegetable Seeds Ibérica, S.A., Paraje San Nicolás, 04740 La Mojonera, Almería, Spain; and fifth author: Centro de Edafología y Biología Aplicada del Segura (CEBAS), Consejo Superior de Investigaciones Científicas, 30100 Campus Universitario de Espinardo, Murcia, Spain.
\end{abstract}

Accepted for publication 10 February 2003.

\begin{abstract}
Marco, C. F., Aguilar, J. M., Abad, J., Gómez-Guillamón, M. L., and Aranda, M. A. 2003. Melon resistance to Cucurbit yellow stunting disorder virus is characterized by reduced virus accumulation. Phytopathology 93:844-852.

The pattern of accumulation of Cucurbit yellow stunting disorder virus (CYSDV; genus Crinivirus, family Closteroviridae) RNA has been analyzed in several cucurbit accessions. In susceptible accessions of melon (Cucumis melo), cucumber (Cucumis sativus), marrow (Cucurbita maxi$m a$ ), and squash (Cucurbita pepo), CYSDV RNA accumulation peaked during the first to second week postinoculation in the first to third leaf above the inoculated one; younger leaves showed very low or undetectable levels of CYSDV. Three melon accessions previously shown to remain asymptomatic after CYSDV inoculation under natural conditions

very low CYSDV levels were detected by RT-PCR in whitefly-inoculated leaves, and therefore, multiplication or spread of CYSDV in C-105 plants appeared to remain restricted to the inoculated leaves. When C-105 plants were graft inoculated, CYSDV RNA could be detected in phloem tissues, but the systemic colonization of C-105 by CYSDV upon graft inoculation seemed to be seriously impeded. Additionally, in situ hybridization experiments showed that, after C-105 graft inoculation, only a portion of the vascular bundles in petioles and stems were colonized by CYSDV and virus could not be found in leaf veins. RT-PCR experiments using primers to specifically detect negative-sense CYSDV RNA were carried out and showed that CYSDV replication took place in graftinoculated C-105 scions. Therefore, the resistance mechanism may involve a restriction of the virus movement in the vascular system of the plants and/or prevention of high levels of virus accumulation.
\end{abstract} were also assayed for their susceptibility to CYSDV. Hybridization and reverse transcription-polymerase chain reaction (RT-PCR) analysis of noninoculated leaves showed that only one of these, C-105, remained virus-free for up to 6 weeks after whitefly inoculation. In this accession,
Additional keywords: Bemisia tabaci, closterovirus, plant-virus interaction, systemic movement, tolerance.
Cucurbit yellow stunting disorder virus (CYSDV) is a closterovirus transmitted in nature by the whitefly Bemisia tabaci (Gennadius). CYSDV was first detected in 1982 in the United Arab Emirates (9), and since then, it has been found in Spain, Portugal, Morocco, Lebanon, and North America extensively affecting cucurbit crops $(1,3,4,12,20,37)$. CYSDV induces interveinal chlorotic spots in mature leaves which may enlarge and eventually fuse together producing yellowing of the entire leaf except for the veins that remain green $(3,37)$. Yellowing symptoms are accompanied by substantial reductions of fruit yield and quality and, therefore, this virus has a high economic importance. CYSDV is a member of the genus Crinivirus (family Closteroviridae) (22). Its viral particles are flexible rods with lengths between 750 to $800 \mathrm{~nm}$ (17). CYSDV has a narrow host range limited to species of Cucurbitaceae (3) in which it is believed to remain confined to phloem-associated cells (13). The CYSDV genome consists of two molecules of single-stranded RNA of positive polarity designated RNAs 1 and 2 (3). Livieratos and Coutts (18) cloned and sequenced cDNAs to the RNA 2 of a CYSDV isolate, but the nucleotide sequence of the RNA 1 has not been published. The genetic diversity of CYSDV isolates from different areas of the world has been studied for the

Corresponding author: M. A. Aranda; E-mail address: m.aranda@cebas.csic.es

Publication no. P-2003-0505-02R

(c) 2003 The American Phytopathological Society heat shock protein 70 homologue (HSP70h) and the coat protein genes of RNA 2. The genetic diversity of CYSDV isolates is unusually low compared with other members of the family Closteroviridae, although it is still possible to differentiate two genetic groups, the so-called eastern and western CYSDV subpopulations $(30,31)$.

The control of CYSDV is currently based on chemical treatments against its vector and preventive cultural practices, both with limited success. The use of genetically resistant cultivars is a good option for CYSDV control, but no resistant cultivar is commercially available. Recently, we reported the existence of possible sources for natural resistance or tolerance to CYSDV (19). In this work, plants of a melon (Cucumis melo L.) accession (C-105) remained asymptomatic after natural or artificial inoculation with CYSDV. Additionally, genetic tests strongly suggested that this character was controlled by a single dominant gene named Cys (19). Because no detection methods were used to specifically analyze the presence CYSDV in C-105 plants, this character could correspond to a tolerance (i.e., lack of symptoms) or to a resistance (i.e., reduction in, or a lack of virus accumulation). The work presented here was aimed at elucidating this aspect and analyzing the mechanism of disease tolerance or resistance of C-105 melon plants to CYSDV. Tools for detection of CYSDV RNAs in plant tissues were developed and the accumulation of CYSDV in C-105 and related cultivars or species was studied. Results of our work indicate that C-105 plants are resistant to CYSDV infection and suggest that the resistance mechanism may involve a restriction of the virus movement in the vascular system of the plants and/or prevention of high levels of virus accumulation. 


\section{MATERIALS AND METHODS}

All standard DNA and RNA manipulations were carried out as described by Sambrook and Russell (32).

Plant, virus, and insect cultures. Cucurbits susceptible to CYSDV used in this study were Cucumis melo cv. Amarillo (C250, La Mayora germplasm collection, Málaga, Spain), Cucumis sativus cv. Bellpuig, Cucurbita maxima cv. Cabello de Angel, and Cucurbita pepo cv. Diamant (Semillas Fitó, Spain). The melon accessions tested for their susceptibility to CYSDV (C-105, C-243, and C-300) belong to the germplasm collection of $\mathrm{La}$ Mayora. Seeds were germinated and grown in a nursery; 15-dayold seedlings were planted in 12-liter pots and kept in an insectproof glasshouse. After 2 weeks, if required, plants were transplanted to 18-liter pots to guarantee proper development. The CYSDV isolate used in this study (CYSDV-AlLM) was obtained from a naturally infected melon plant collected in Almeria (Spain) in 1997, and maintained in La Mayora on Cucumis melo cv. Amarillo through transmission by B. tabaci (B biotype [7]). Samples of this isolate are kept under the accession no. PV0592/EWSN_6 in the DSMZ-Deutsche Sammlung von Mikroorganismen und Zellkulturen $\mathrm{GmbH}$ collection (Braunschweig, Germany). CYSDV-AlLM RNA was prepared by in vitro transcription using T7 RNA polymerase (Promega, Madison, WI) in a standard reaction (32) in which the plasmid pLM15, linearized with $K p n I$, was used as template.

For whitefly transmission experiments, virus-free B. tabaci colonies were maintained on healthy melon plants (Cucumis melo cv. Amarillo) in an insect-proof glasshouse $\left(20\right.$ to $32^{\circ} \mathrm{C}, 45$ to $85 \%$ relative humidity $[\mathrm{RH}])$ with artificial light supplemented when needed.

Whitefly and graft inoculations. Whitefly inoculation of test plants with CYSDV was performed essentially as described by López-Sesé and Gómez-Guillamón (19). Briefly, groups of adult whiteflies were given a $24 \mathrm{~h}$ acquisition access period by feeding on virus source melon plants (Cucumis melo cv. Amarillo). Following the acquisition access period, whiteflies were given a $48 \mathrm{~h}$ inoculation access period on test plants using 60 whiteflies per plant. Plants for inoculation were about 4 weeks old, with the first true leaf fully expanded. Acquisition and inoculation were performed using home-made clip-on cages. After the inoculation access period, whiteflies were carefully removed and plants were treated with insecticide. Fifteen days after inoculation, the leaves on which the whiteflies had fed and laid their eggs were removed. Control plants were obtained following the same scheme but using virus-free whiteflies.

For graft inoculation, Cucumis melo cv. Amarillo plants were whitefly inoculated as described to produce the stocks needed. Ten days after inoculation, the leaves where the whiteflies had fed were removed and analyzed for CYSDV infection by hybridization on tissue prints of petiole cross-sections (described below). Only plants that showed an intense hybridization signal were used as virus sources. Infected plants were cut at the internodal stem region above the third leaf and the basal part of the plant was kept to be used as a virus-infected stock. To produce the scions, $\mathrm{Cucu}$ mis melo plants (accession C-105 and cv. Amarillo as susceptible control) were grown in the greenhouse for 6 weeks and pruned twice during this period to obtain as many side shoots as possible. The apical parts of the stems of these plants (approximately 7 to $8 \mathrm{~cm}$ long) were collected, given a $\mathrm{V}$ shape at the cut end, and grafted onto the stock. The graft region was wrapped with Parafilm M (American National Can, Chicago, IL) and a high RH (60 to $80 \%$ ) was maintained in the greenhouse during the following 2 days to avoid dehydration of the scion. Following this procedure, around $80 \%$ of the scions survived and the rate of successful infections of susceptible scions was $100 \%$.

The results of the grafting experiments were compared by means of an analysis of variance after arcsine transformation (34).
Establishment of the signification groups was carried out by using the least significant difference test at $P=0.01$ (SAS system; SAS Institute, Cary, NC).

Detection of CYSDV RNA in tissue prints. For detection of CYSDV positive-sense RNA in tissue prints (23), plant stems, petioles, and major leaf veins were cut with a razor blade and, immediately after cutting, the cross-sections were blotted onto positively charged nylon membranes (Roche Diagnostics $\mathrm{GmbH}$, Mannhein, Germany). CYSDV RNA on membranes was detected by molecular hybridization with an RNA digoxigenin (DIG)labeled probe (see in situ hybridization) according to the manufacturer's recommendations (Roche Diagnostics). Briefly, prehybridization and hybridization of membranes were carried out at $65^{\circ} \mathrm{C}$ in standard buffer $(5 \times \mathrm{SSC}[1 \times \mathrm{SSC}$ is $0.15 \mathrm{M} \mathrm{NaCl}$ plus $0.015 \mathrm{M}$ sodium citrate], $0.1 \% \mathrm{~N}$-Lauroylsarcosine, $0.02 \%$ sodium dodecyl sulfate, and $2 \%$ blocking reagent [Roche Diagnostics]) containing 50\% formamide. Membranes were washed for $15 \mathrm{~min}$, once at room temperature in $2 \times \mathrm{SSC}$ and twice at $65^{\circ} \mathrm{C}$ in $0.1 \times$ SSC. Chemiluminescent detection was carried out using the reagents and protocols supplied by the DIG-labeling and detection kit (Roche Diagnostics).

CYSDV RNA quantification in dot blots. The amount of CYSDV positive-sense RNA present in leaf samples was estimated from dot blot hybridization signals. For this, two to three disks $(1.5 \mathrm{~cm}$ in diameter) were taken from different parts of each leaf and total RNA was extracted from them following the protocol described by Célix et al. (3). Aliquots of each extract were analyzed by electrophoresis in agarose gels to check RNA integrity and to quantify total RNA. Melon total RNA extracts of known RNA concentration were included as standards. For each analyzed sample, $1 \mu \mathrm{l}$ from the total RNA extract and $1 \mu \mathrm{l}$ of a 1:10 dilution were spotted onto a nylon membrane. Additionally, $1 \mu \mathrm{l}$ of CYSDV-transcribed RNA at a concentration of $40 \mu \mathrm{g} / \mathrm{ml}$ plus a dilution series were spotted onto the membrane. Blots were then subjected to UV RNA cross linking, prehybridized, hybridized, washed, and developed to detect CYSDV RNA as described previously. Membranes were exposed to X-ray films and the resulting autoradiographs were transiluminated and their image acquired by a digital camera. Digitized images were computer analyzed to quantify the intensity of the signal on each dot. Dots corresponding to the samples of CYSDV-transcribed RNA provided the values to calibrate the relationship between signal intensity and amount of viral RNA. This calibration served to interpolate the values for the amounts of viral RNA in the test samples. Eventually, the amount of CYSDV RNA was referred to as the amount of total RNA for each extract.

Detection of CYSDV RNAs by reverse transcription-polymerase chain reaction. For reverse transcription-polymerase chain reaction (RT-PCR) detection of positive-sense CYSDV RNA, two primers that would produce a DNA fragment of about $540 \mathrm{bp}$ were designed based on the nucleotide sequence of the $3^{\prime}$-terminal region of CYSDV RNA 1 (J. M. Aguilar, M. Franco, C. F. Marco, B. Berdiales, E. Rodriguez-Cerezo, V. Truniger, and M. A. Aranda, unpublished data). The upstream primer was 5'-GAAGAATTCCAGGCAAGG-3' (MA156) and the downstream primer was 5'-TCACATCATCAATCCAAAAG-3' (MA129). Reverse transcription was performed in a reaction mixture $(20 \mu \mathrm{l})$ containing first strand buffer (Invitrogen BV/Novex, Groningen, the Netherlands), $10 \mu \mathrm{g}$ of total RNA (3), $75 \mu \mathrm{M}$ MA129, $0.5 \mathrm{mM}$ dNTPs, 20 units of ribonuclease inhibitor (Invitrogen), and 200 units of Superscript RNase H reverse transcriptase (Invitrogen). The mixture was incubated at $37^{\circ} \mathrm{C}$ for $1 \mathrm{~h}$. For PCR amplification, $1 \mu \mathrm{l}$ of the synthesized cDNA was added to a tube containing $15 \mu \mathrm{M}$ each primer, $1 \mathrm{mM}$ dNTPs, $3 \mathrm{mM} \mathrm{MgCl}_{2}$, reaction buffer (Bioline, London, UK), and 2.5 units of Taq DNA polymerase (Bioline) in a final volume of $25 \mu \mathrm{l}$. Cycling conditions were as follows: 30 cycles at $94^{\circ} \mathrm{C}$ for $30 \mathrm{~s}, 55^{\circ} \mathrm{C}$ for $30 \mathrm{~s}$, and $72^{\circ} \mathrm{C}$ for $30 \mathrm{~s}$, preceded by an initial incubation of $94^{\circ} \mathrm{C}$ for 

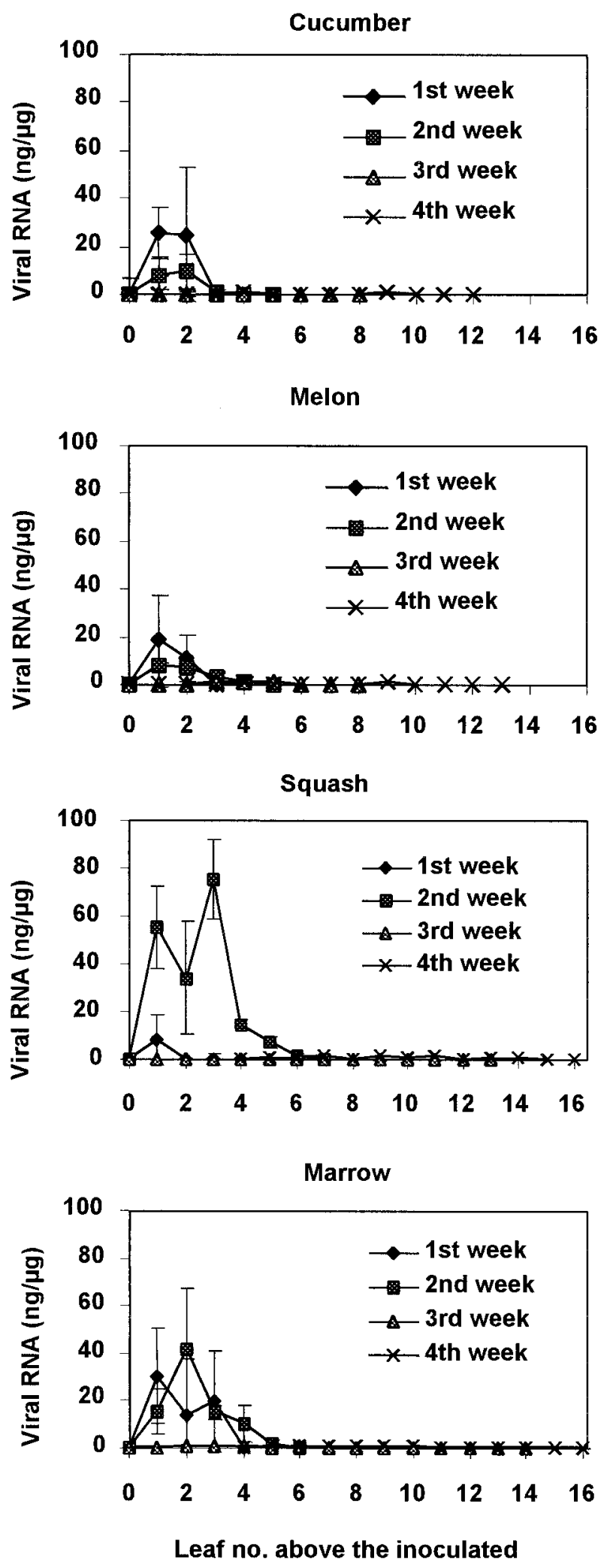

Fig. 1. Accumulation of Cucurbit yellow stunting disorder virus RNA in susceptible accessions of cucumber, melon, squash, and marrow. Numbers in the horizontal axis represent the relative position of the leaf sampled with respect to the inoculated leaf (the inoculated leaf was considered leaf number 0 ). The average amounts of viral RNA are expressed in nanograms per microgram of total plant RNA and are represented in the vertical axis. Each value corresponds to the average viral RNA content of leaf samples from eight independent plants. Bars equal the standard deviation for each value. The amounts of viral RNA were estimated by quantification of hybridization signals in dot blots of total RNA extracted from leaf tissues. Samplings were carried out at four consecutive time points every other week.
$5 \mathrm{~min}$, and followed by a final incubation at $72^{\circ} \mathrm{C}$ for $7 \mathrm{~min}$. For RT-PCR detection of negative-sense CYSDV RNA, primers that would produce a DNA fragment of about $560 \mathrm{bp}$ were designed based on the nucleotide sequence of the 3'-terminal region of CYSDV RNA 1 (J. M. Aguilar, M. Franco, C. F. Marco, B. Berdiales, E. Rodriguez-Cerezo, V. Truniger, and M. A. Aranda, unpublished data). The primer for first strand cDNA synthesis was 5'-CGAAGTTTGTGCAATGCCTGACCGAAGAATTCCAGGCAAGG-3' (MA230), which included a 3'-end portion identical to a nucleotide sequence of the positive-sense CYSDV RNA 1 and a nonviral $5^{\prime}$-end portion (underlined). Twenty micrograms of total nucleic acids (TNA) extracts was used as template for reverse transcription; TNA extracts were obtained as described by Célix et al. (3), except that $\mathrm{LiCl}$ precipitation was substituted by an ethanol precipitation. Other reverse transcription conditions were as described for the detection of positive-sense CYSDV RNA. After reverse transcription, 100 units of RNase A (Roche Diagnostics) was added to the mixture and incubation proceeded at $95^{\circ} \mathrm{C}$ for $5 \mathrm{~min}$ and then at $37^{\circ} \mathrm{C}$ for $20 \mathrm{~min}$. The resulting products were purified in a Microcon YM-100 (Millipore Corp., Bedford, MA). One microliter of the prepared cDNA was used in PCR amplification reactions in which primers MA129 and 5'CGAAGTTTGTGCAATGCCTGACC-3' (MA225) were used, the latter being the nonviral nucleotide sequence included in MA230. PCR conditions were as described for detection of positive-sense CYSDV RNA. RT-PCR products were fractionated by electrophoresis in $1.2 \%$ agarose gels and visualized after ethidium bromide staining.

Cytological detection of CYSDV RNA by in situ hybridization. A DIG-11-UTP-labeled RNA probe to detect the positivesense CYSDV RNA was synthesized by in vitro transcription from the plasmid pLM15. Plasmid pLM15 was linearized with $X b a I$ for transcription of negative-sense RNA using SP6 RNA polymerase (Promega). Transcripts were sheared to fragments of about 150 bp by alkaline hydrolysis to improve the in situ hybridization signal. This probe was hybridized to tissue sections and detected using an alkaline phosphatase-conjugated anti-DIG antibody as described previously; 5-bromo-4-chloro-3-indoylphosphate and nitro-blue tetrazolium were used as chromogenic substrates $(2,36)$. The probe was also used for dot blot and tissue print hybridizations (described previously).

Melon tissues were fixed in $4 \%$ formaldehyde and prepared for in situ hybridization according to Jackson (11). Processed sections were mounted in Shandon Mount Toluene Base (Shandon, Pittsburgh, PA) with a prior counterstaining in $0.1 \%$ Calcofluor (Sigma Chemical, St. Louis) and were photographed using transmitted light microscopy or combined epifluorescence (UV; Calcofluor staining of cell walls) and transmitted light microscopy.

\section{RESULTS}

Accumulation of CYSDV in whitefly-inoculated cucurbits. The kinetics of CYSDV RNA accumulation in whitefly-inoculated cucurbits was studied in a time course experiment. Eight plants of melon, cucumber, squash, and marrow accessions known to be susceptible to CYSDV were whitefly inoculated with CYSDV-AlLM and maintained in an insect-proof glasshouse for 4 weeks after inoculation. CYSDV-AlLM has been analyzed at the molecular level having a nucleotide sequence similarity in the HSP70h gene close to $100 \%$ with the CYSDV isolate characterized by Célix et al. (3; J. M. Aguilar, M. Franco, C. F. Marco, B. Berdiales, E. Rodriguez-Cerezo, V. Truniger, and M. A. Aranda, unpublished data). During this period, leaf samples were taken at weekly intervals from every leaf of each plant. Total RNA was extracted from the samples and the amount of CYSDV RNA present in these extracts was quantified by dot blot hybridization. The probe for hybridizations was synthesized from the plasmid pLM15, which contains a cDNA insert of about $5 \mathrm{kbp}$ corre- 
sponding to a central region of CYSDV RNA 1 (J. M. Aguilar, M. Franco, C. F. Marco, B. Berdiales, E. Rodriguez-Cerezo, V. Truniger, and M. A. Aranda, unpublished data). As shown in Figure 1, the overall pattern of CYSDV RNA accumulation was similar for all hosts. CYSDV RNA accumulation reached a peak during the first to second week postinoculation in the first to third leaf above the inoculated one. After the second week postinoculation, the titer of CYSDV RNA decreased drastically. However, virus levels differed up to fourfold between hosts during the observation period. For example, in melon, maximum viral RNA content was around $20 \mathrm{ng}$ per $\mu \mathrm{g}$ of total plant RNA in the first sampling (1 week postinoculation), whereas in squash, maximum viral RNA content was around $80 \mathrm{ng}$ per $\mu \mathrm{g}$ of total plant RNA in the second sampling ( 2 weeks postinoculation; Fig. 1). Symptom development was slightly delayed with respect to CYSDV RNA accumulation; primary symptoms developed as a mild interveinal chlorotic mottling during the second week postinoculation and were more intense in the first and second leaves above the inoculated leaf. These results suggested that samplings for the routine analysis of susceptibility to CYSDV should be carried out during the second week postinoculation on the second leaf above the inoculated one, where maximum viral RNA content would occur. Following this procedure, we analyzed three melon accessions (C-105, C-243, and C-300) that in previous studies did not show the characteristic yellowing symptoms of CYSDV infection after whitefly inoculation (19; C. F. Marco, A. López-Sesé, M. L. Gómez-Guillamón, and M. A. Aranda, unpublished data). As shown in Table 1, except for C-105 in which no viral RNA was detected in three independent experiments done at different times of the year, CYSDV RNA was clearly detected in C-243 and C300 as well as in the susceptible control C-250. Moreover, systemic yellowing symptoms could be observed occasionally in C-243 and C-300. Therefore, out of the three candidate accessions, only C-105 appeared to be resistant to CYSDV upon whitefly inoculation.

Accumulation of CYSDV in whitefly-inoculated C-105 plants. To analyze whether the lack of CYSDV detection in inoculated C-105 plants was due to delayed virus colonization, we studied the accumulation of CYSDV in C-105 tissues at late times after inoculation. Two groups of 10 whitefly-inoculated plants were analyzed to detect CYSDV at 4 and 6 weeks after inoculation, respectively. As shown in the previous section, dot blot hybridization signal is very low for susceptible hosts after the second week postinoculation (Fig. 1). Therefore, for this analysis we used two different methods for CYSDV detection, hybridization on tissue prints of petiole cross-sections and RT-PCR on total RNA extracts. Whereas CYSDV could be detected in susceptible controls by hybridization on tissue prints of petiole crosssections, no virus-specific signal could be observed in C-105 plants using the same detection method (data not shown). Moreover, when total RNA extracts were obtained from leaves sampled

TABLE 1. Susceptibility of melon accessions to Cucurbit yellow stunting disorder virus (CYSDV) infection after controlled inoculation with Bemisia tabaci $^{\mathrm{x}}$

\begin{tabular}{lcccr}
\hline & \multicolumn{4}{c}{ No. of positive plants/no. of inoculated plants } \\
\cline { 2 - 5 } Accession & Experiment 1 & Experiment 2 & Experiment 3 & Total \\
\hline C-105 & $0 / 14$ & $0 / 5$ & $0 / 5$ & $0 / 24$ \\
C-243 & $8 / 14$ & - & - & $8 / 14$ \\
C-300 & $0 / 14$ & $5 / 10$ & $15 / 20$ & $20 / 44$ \\
C-250 & $8 / 14$ & $3 / 5$ & $6 / 9$ & $17 / 28$ \\
\hline
\end{tabular}

${ }^{x}$ Up to three independent experiments were carried out during different times of the year.

y Plants were sampled during the second week postinoculation, and the second leaf above the inoculated leaf was analyzed for the presence of CYSDV by RNA-RNA hybridization.

${ }^{\mathrm{z}}$ This accession was included as a susceptible control. at 6 weeks after inoculation and analyzed by RT-PCR, no virus could be detected in C-105 plants (Fig. 2A, compare lanes 2 and 3 which correspond to a susceptible control with lanes 4 and 5 which correspond to a C-105 plant). The accumulation of CYSDV in whitefly-inoculated leaves was also analyzed. Leaf tissues where whiteflies had fed were sampled from three inoculated C105 plants and two susceptible controls 2 weeks after inoculation and used for total RNA extraction. Prior to extraction, leaf samples were carefully examined and washed to remove any possible whitefly remnant. RNA extracts were then used to detect CYSDV RNA by dot blot hybridization and by RT-PCR. When extracts of inoculated leaves of the susceptible control were analyzed, hybridization signal was clearly detected and an abundant DNA fragment of the expected size was observed after electrophoresis of the RT-PCR products (Fig. 2B, lanes 2 and 3). In contrast, when extracts of inoculated $\mathrm{C}-105$ leaves were analyzed by dot blot, no signal above background was observed, although we observed a faint band corresponding to a DNA fragment of the expected size after electrophoresis of the RT-PCR products (Fig. 2B, lanes 4 and 5). Therefore, these data suggest that CYSDV accumulated in whitefly-inoculated C-105 leaves, but the virus seemed to be present in a small area and/or at lower concentrations within that area.

Accumulation of CYSDV in graft-inoculated C-105 plants. Sixty-four cuttings from 12 different C-105 plants were grafted onto 64 infected stocks. Every grafted plant was analyzed for CYSDV infection by hybridizing tissue prints of cross-sections of

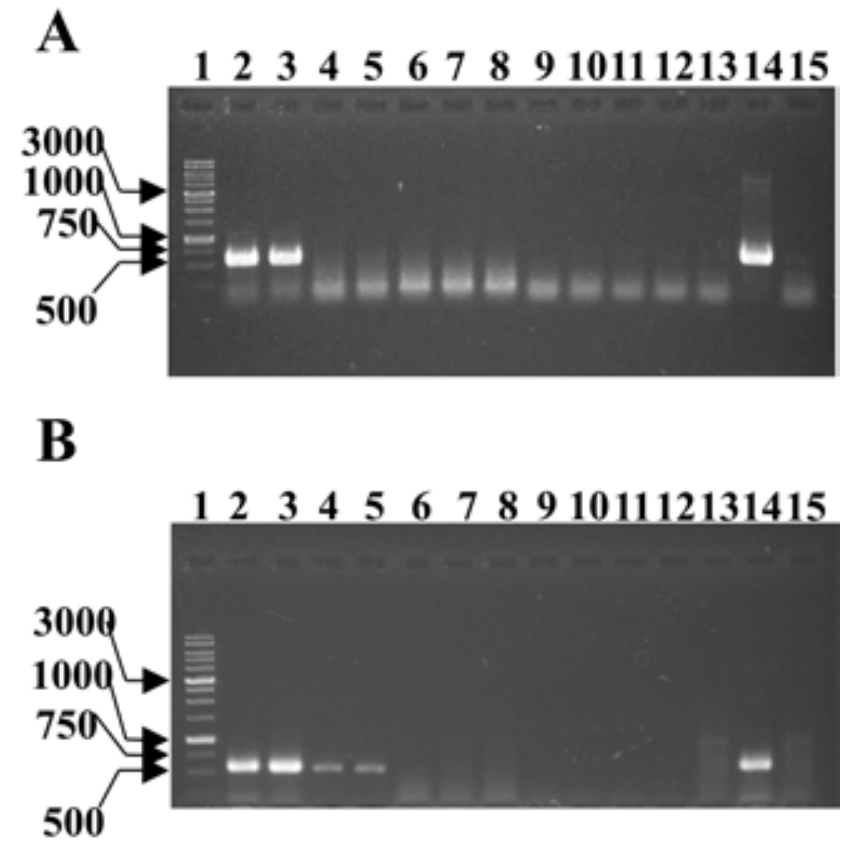

Fig. 2. Agarose gel electrophoresis of reverse transcription-polymerase chain reaction (RT-PCR) products for the detection of Cucurbit yellow stunting disorder virus (CYSDV) RNA in melon plants. A, Detection of CYSDV RNA in total RNA extracted from leaves 15 to 20 above the whiteflyinoculated leaves at 6 weeks after inoculation. B, Detection of CYSDV RNA in total RNA extracted from whitefly-inoculated leaves at 2 weeks after inoculation. Extracts in lanes 2 and 3 were from susceptible whitefly-inoculated melon plants. Extracts in lanes 4 and 5 were from C-105 whiteflyinoculated plants. Negative controls include: RT-PCR on extracts from healthy susceptible melon plants (lanes 6 and 7); RT-PCR on extracts from healthy C-105 melon plants (lanes 8 and 9); RT-PCR in the absence of reverse transcriptase on extracts from infected susceptible melon plants (lanes 10 and 11); RT-PCR in the absence of the primer for the cDNA first-strand synthesis during reverse transcription on extracts from infected, susceptible melon plants (lanes 12 and 13); and RT-PCR in the absence of RNA (lane 15). One nanogram of the plasmid pLM44 was included as a positive control for the PCR reaction (lane 14). DNA molecular size markers were included (lane 1); positions of markers (base pair) are shown on the left. 
stems and petioles from six different positions of the plant at 28 days postinoculation. Figure $3 \mathrm{~A}$ shows a drawing of a plant in which a C-105 scion was grafted onto a CYSDV-infected stock; the positions of the plant in which samples were taken for analyses are indicated on the right. An example of an autoradiograph of a membrane hybridized to detect CYSDV is shown in Figure 3B. As summarized in Table 2, all the scions of the susceptible control but not all of the C-105 were infected. Additionally, although there were no significant differences between the proportion of infected scions found at different positions in the plant for the susceptible control (100\% positive at any position), significant differences were observed between positions for $\mathrm{C}-105$. Thus, the proportion of $\mathrm{C}-105$ scions infected with $\mathrm{CYSDV}$ at positions close to the apex were significantly less $(P \leq 0.01)$ than the proportion of scions infected with CYSDV at positions proximal to the graft union (Table 2). Also, the intensity of the hybridization signal was lower for scions of C-105 than for scions of the susceptible control (Fig. 3B, compare columns 1 to 3 with columns 5 to 20). These results indicate that CYSDV could colonize systemically graft-inoculated C-105 scions but less efficiently than susceptible controls. Interestingly, all the C-105 scions remained totally asymptomatic by 28 days after grafting, whereas all the scions of the susceptible accession grafted onto infected plants showed clear yellowing symptoms by the same time.

In order to analyze whether or not replication of CYSDV occurred in C-105 plants, we studied the presence of CYSDV negative-sense RNA in plant TNA extracts by RT-PCR using specific primers. TNA extracts were obtained from grafted plants sampled at plant position V (scion stem; Fig. 3A) at 28 days after grafting. After electrophoresis of the RT-PCR products in agarose gels, a DNA fragment of the expected size was observed in lanes corresponding to TNA extracts of the graft-inoculated C-105 scions (Fig. 4, lanes 2 to 4). This DNA fragment was excised from the agarose gels, purified, and directly sequenced; its nucleotide sequence fully coincided with the nucleotide sequence expected to be amplified. No DNA fragments were observed when TNA extracts were from grafted healthy plants (Fig. 4, lanes 5 and 6) or when the extracts were from the graft-inoculated C-105 scions but either the reverse transcriptase (Fig. 4, lanes 7 to 9) or the oligonucleotide used for the first strand synthesis (Fig. 4, lanes 10 to 12) were omitted in the RT-PCR reaction. These results strongly suggest that CYSDV replication took place in C-105 plants.

Cytological detection of CYSDV in graft-inoculated C-105. Tissue sections of graft-inoculated C- 105 plants were analyzed by in situ hybridization to determine if CYSDV RNA localized to particular tissues. Stem, petiole and leaf cross-sections were prepared for in situ hybridization from melon scions sampled at position V (Fig. 3A) 28 days after grafting, and at least two plants from each treatment were analyzed during each in situ hybridization experiment. Figure 5A shows a typical internodal section $(6,14)$ of a melon stem; sections in Figure $5 \mathrm{~B}$ to $\mathrm{E}$ are from the same relative position of the stem indicated in Figure 5A. In stem and petiole sections of susceptible graft-inoculated melon plants, virus-specific signal was clearly detected in the fascicular phloem of every vascular bundle, particularly in bundle-associated cells (compare the healthy control in Fig. 5B with Fig. 5C). Signal was often observed in extrafascicular phloem cells (data not shown), but we never detected any signal in nonphloem cells. When stem and petiole sections of graft-inoculated C-105 were assayed by in situ hybridization, virus-specific signal was perceptible in cells of the fascicular phloem, but it was much less abundant than in sections of the susceptible accession and it was not present in every vascular bundle but only in a subset with the larger sizes (14 of 76 vascular bundles analyzed; Fig. 5D and E). Thus, virus accumulated nonuniformly in stems and petioles of C-105 scions. In sections of leaves of a susceptible graft-inoculated accession, virus-specific signal was present in most veins (compare the healthy control in Fig. 6A with Fig. 6B) more often in external than in internal phloem (Fig. 6B). In contrast, no virus-specific

\section{A B}

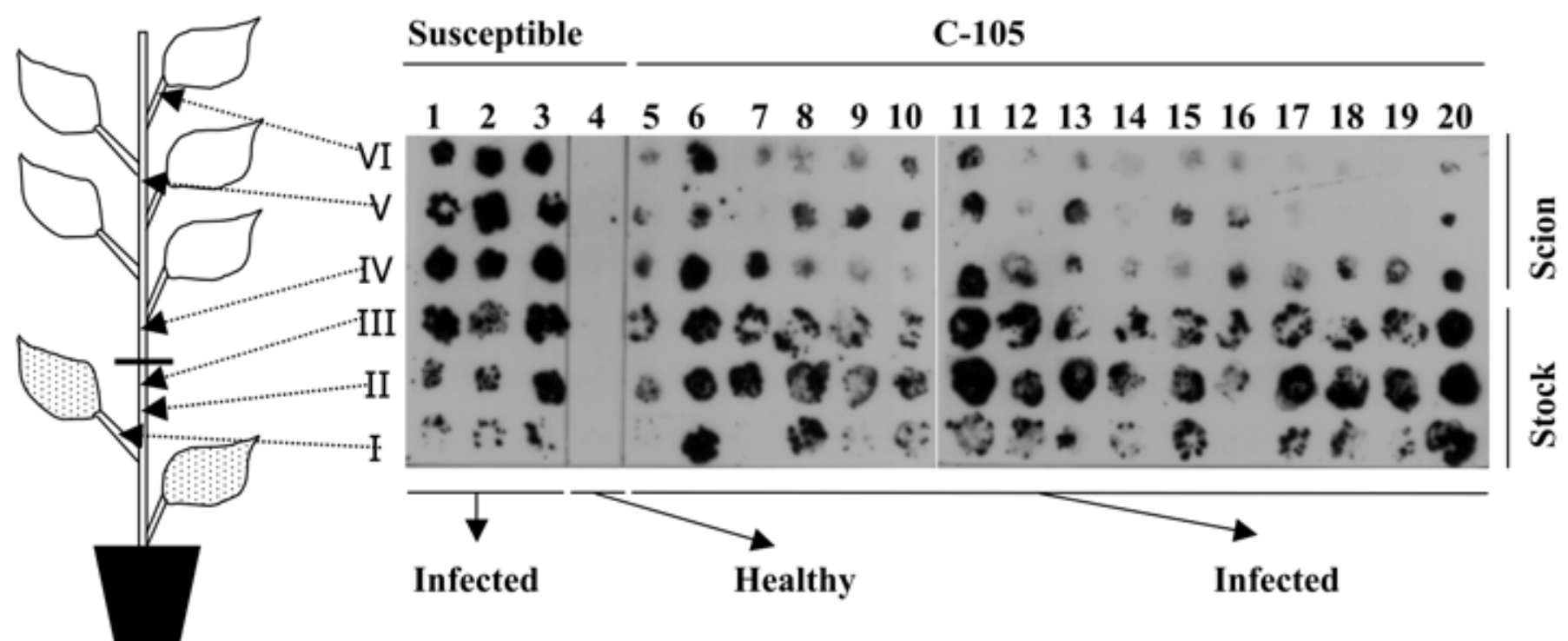

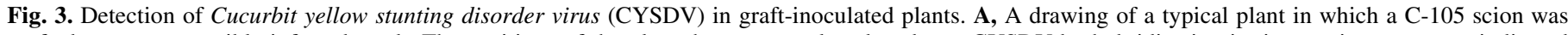

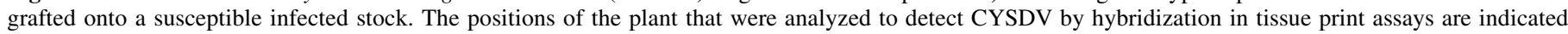

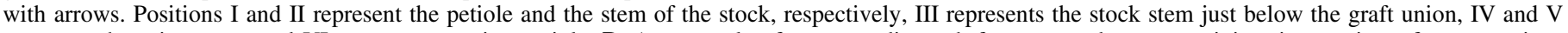

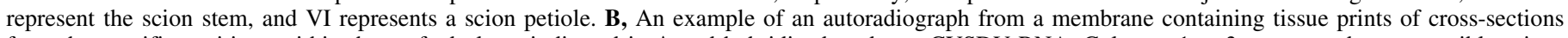

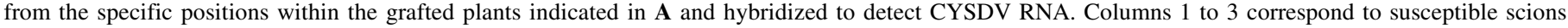

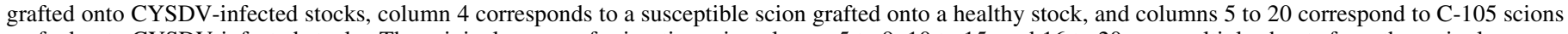

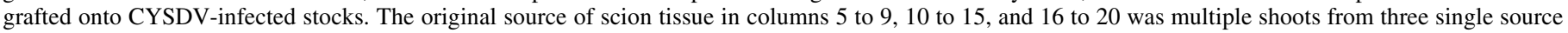
plants. 
signal could be detected in any of the graft-inoculated C-105 leaf veins examined (Fig. 6C).

\section{DISCUSSION}

To our knowledge, the only description of possible sources for natural resistance to CYSDV comes from our previous studies that suggested that plants of a melon accession, C-105, could carry such a resistance. In those studies, the disease diagnosis was done by symptom observation, and therefore, those results could not explain if the lack of symptoms were related to resistance to symptom expression (i.e., tolerance) or resistance to CYSDV multiplication and/or spread in the plant. To analyze this matter, we developed qualitative and quantitative methods for the detection of CYSDV RNA and used them to determine, firstly, the pattern of accumulation of CYSDV RNA in susceptible cucurbits and, secondly, whether accumulation of CYSDV RNA occurred in melon accessions previously shown to resist visual disease development. We found that in susceptible accessions of melon, cu-

TABLE 2. Cucurbit yellow stunting disorder virus (CYSDV) detection in tissue prints of graft-inoculated plants ${ }^{\mathrm{x}}$

\begin{tabular}{lcc}
\hline \multirow{2}{*}{$\begin{array}{l}\text { Plant } \\
\text { position }^{\mathrm{y}}\end{array}$} & \multicolumn{2}{c}{ No. of positive plants/no. of tested plants (frequency; group) } \\
\cline { 2 - 3 } & Plants with C-105 scions & Plants with susceptible scions \\
\hline I & $54 / 64(0.84 \mathrm{~b}, \mathrm{c})$ & $11 / 11(1.00 \mathrm{c})$ \\
II & $61 / 64(0.95 \mathrm{~b}, \mathrm{c})$ & $11 / 11(1.00 \mathrm{c})$ \\
III & $64 / 64(1.00 \mathrm{c})$ & $11 / 11(1.00 \mathrm{c})$ \\
IV & $60 / 64(0.94 \mathrm{~b}, \mathrm{c})$ & $11 / 11(1.00 \mathrm{c})$ \\
V & $44 / 64(0.69 \mathrm{a})$ & $11 / 11(1.00 \mathrm{c})$ \\
VI & $45 / 64(0.70 \mathrm{a})$ & $11 / 11(1.00 \mathrm{c})$ \\
\hline
\end{tabular}

${ }^{\mathrm{x}} \mathrm{C}-105$ and susceptible (Cucumis melo cv. Amarillo) scions were graft inoculated. Detection of CYSDV was performed by hybridization on tissue prints of cross-sections of plant stems and petioles at 28 days after inoculation. Sixty-four scions from 12 different C-105 plants were tested; 11 scions from susceptible plants were included as positive controls.

${ }^{y}$ Different positions on the grafted plants were analyzed. Positions I and II represent the petiole and stem of the stock, respectively, III represents the stock stem just below the graft union, IV and V represent the scion stem, and VI represents a scion petiole (positions I to VI represent older to younger tissue in the plant as indicated in Figure 3A).

$\mathrm{z}$ Values followed by different letters differ significantly $(P \leq 0.01)$ according to the least significant difference test (SAS Institute, Cary, NC).

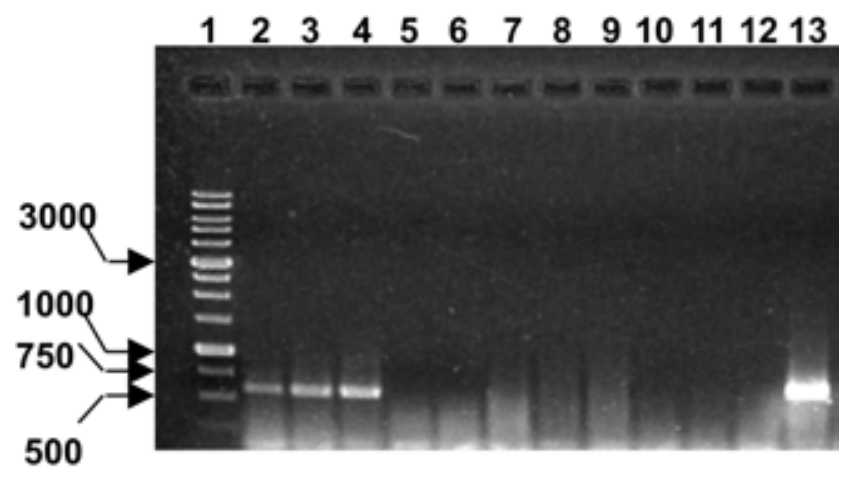

Fig. 4. Agarose gel electrophoresis of reverse transcription-polymerase chain reaction (RT-PCR) products for the detection of Cucurbit yellow stunting disorder virus negative-sense RNA in C-105 graft-inoculated melon plants. Total nucleic acids (TNA) extracted from position V of C-105 graft-inoculated plants sampled 28 days after grafting (Fig. 3A) were used in lanes 2 to 4. Negative controls include: RT-PCR on TNA extracts from healthy C-105 plants (lanes 5 and 6); RT-PCR in the absence of reverse transcriptase on TNA extracts as in lanes 2 to 4 (lanes 7 to 9); and RT-PCR in the absence of the primer for the cDNA first-strand synthesis in the reaction of reverse transcription on TNA extracts as in lanes 2 to 4 (lanes 10 to 12). A TNA extract from a susceptible graft-inoculated plant was used in lane 13. DNA molecular size markers were included (lane 1); positions of markers (base pair) are shown on the left.
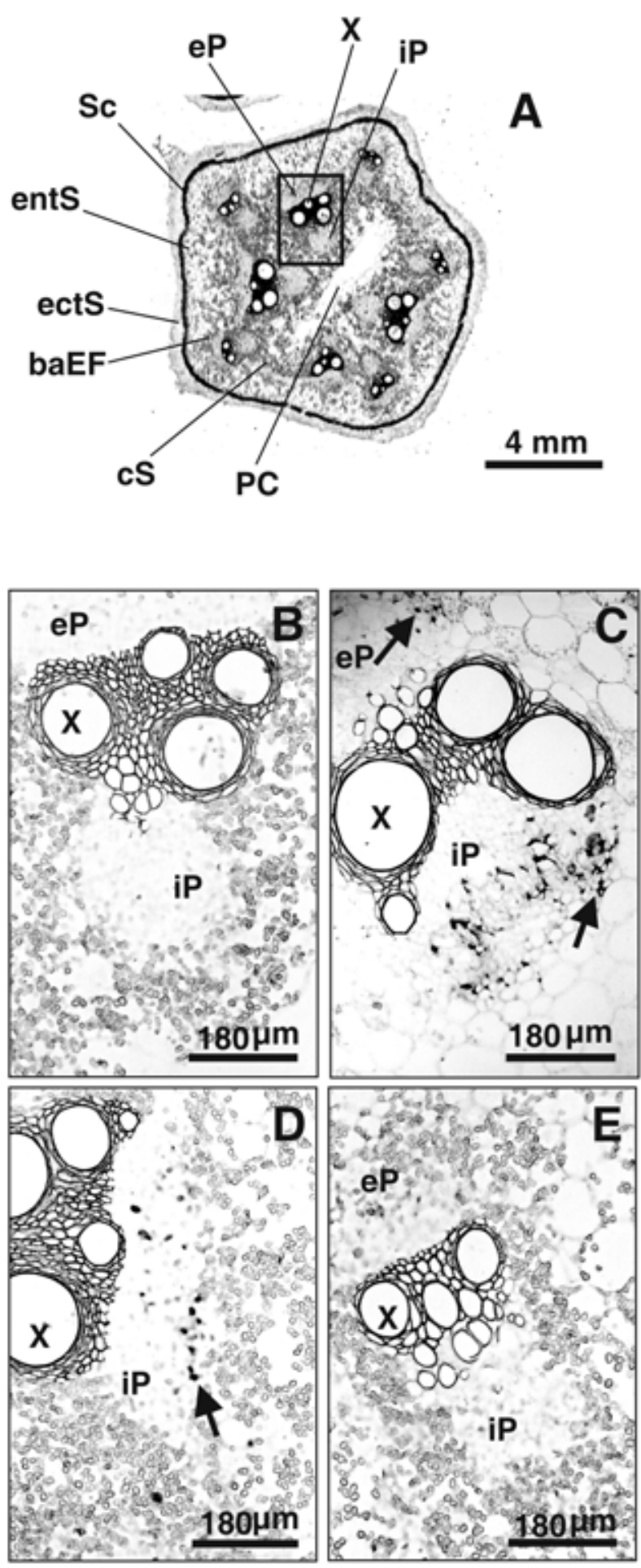

Fig. 5. Detection of Cucurbit yellow stunting disorder virus (CYSDV) RNA in cross-sections of stems of graft-inoculated plants by in situ hybridization. A, A typical internodal cross-section of a melon stem. Bicollateral vascular bundles are composed of internal (iP) and external (eP) fascicular phloem flanking the xylem $(\mathrm{X})$ on two sides. The extrafascicular phloem consists of entocyclic (entS) and ectocyclic (ectS) phloem strands separated by a sclerenchyma ring $(\mathrm{Sc})$ in the cortex and commissural sieve elements $(\mathrm{cS})$ forming lateral connections between the longitudinal phloem strands. Bundle-associated extrafascicular phloem (baEF) is located in arcs bordering the internal and external bundle phloem. A pith cavity (PC) is present in melon stems. Relative positions of vascular bundles that are magnified in the contiguous panels are indicated. B, Vascular bundle in a tissue section of a susceptible scion grafted onto a healthy stock. C, Vascular bundle in a tissue section of a susceptible scion grafted onto a CYSDV-infected stock. D and E, Vascular bundle in a tissue section of a C-105 scion grafted onto a CYSDV-infected stock showing areas D, containing CYSDV RNA or E, lacking CYSDV RNA. The dark spots (indicated by arrows) correspond to CYSDV-specific in situ hybridization signal. Magnification bars are shown. 
cumber, marrow, and squash, CYSDV RNA accumulation peaked during the first to second weeks after inoculation in the first to third leaves above the inoculated one; younger leaves showed very low or undetectable levels of CYSDV. In this respect, CYSDV infections seemed to progress differently than infections with other viruses in which younger leaves had the higher virus titers early after inoculation (10), but paralleled infections with other closteroviruses in which older leaves had the higher virus titers $(15,27)$. This could reflect a defect of phloem cells of young leaves for the support of the replication or the movement of closteroviruses, as has been hypothesized at least in one other occasion (15). In any case, our results suggest that for the routine susceptibility tests it would be appropriate to analyze CYSDV content in the second leaf above the inoculated one at 2 weeks after inoculation. We followed this procedure to study the response of three melon accessions which in previous tests did not show yellowing symptoms. Out of these three accessions, only C105 , in three independent experiments, showed absence of CYSDV, and therefore we concluded that C-105 carried a resistance to CYSDV multiplication or spread in the plant. To analyze the possibility that the lack of CYSDV detection in inoculated C105 plants was due to delayed virus colonization, plants were analyzed at later times after inoculation. Again, no CYSDV was detected in C-105 leaves different than the inoculated ones even using RT-PCR for the CYSDV detection. In contrast, when we examined C-105 whitefly-inoculated leaves, we detected CYSDV RNA by RT-PCR. Our RT-PCR detection technique was not quantitative, but the amounts of DNA products observed after ethidium bromide staining of agarose gels suggest that the amount of CYSDV RNA in C-105-inoculated leaves was less than in inoculated leaves of susceptible controls (Fig. 2B); moreover, when dot blot hybridization was used to detect CYSDV RNA in inoculated leaves, no signal above background was observed in dots corresponding to inoculated C-105 leaves. Taken together, our results suggested that CYSDV multiplication or spread in C105 plants was limited to a few cells of the whitefly-inoculated leaves. To gain a deeper insight into the mechanisms restricting CYSDV infections of C-105 plants, we inoculated plants through grafting and analyzed them to detect CYSDV RNAs. Results of hybridization in prints of stem and petiole cross-sections indicated that CYSDV was present in C-105 graft-inoculated scions, but the systemic colonization of $\mathrm{C}-105$ by CYSDV upon graft inoculation seemed to be impeded because (i) a lower proportion of C-105 scions grafted on CYSDV-infected stocks showed the presence of CYSDV in the upper positions of the plant compared with the susceptible controls (Table 2), and (ii) hybridization signal was always less intense for tissue prints of C-105 scions than for tissue prints of the susceptible controls (Fig. 3). Additionally, in situ hybridization experiments showed that, after C-105 graft inoculation, only a portion of the vascular bundles in petioles and stems were colonized by CYSDV and virus could not be found in leaf veins (Figs. 5 and 6). Because graft-inoculated C-105 plants were sampled when the stock was fully functional and, presumably, acting as a virus source for the sink tissues of the scion, virusspecific signal detected in sections of these plants could correspond to virus sent from the stock but not replicated in C-105. To analyze this aspect, we used specific primers in RT-PCR experiments to detect negative strand viral RNA; it is well established that negative strand RNA is part of the replicative form of singlestranded positive-sense RNA viruses (10) and that its detection can be used as a marker for viral replication (36). These experiments show clearly that negative strand CYSDV RNA was present in C-105 graft-inoculated scions, indicating that CYSDV replication took place in these scions. Therefore, it is possible that the C-105 resistance to CYSDV is due to restricted movement of the virus in the vascular system of the plants, as is the case for several other host-virus incompatible interactions $(8,16,21)$. Alternatively, it may be that the virus still has difficulty replicating even after it moves such that it accumulates to low levels; in this case, a mechanism could exist in the resistant tissue to prevent high levels of virus accumulation.

The resistance to CYSDV of plants of the melon accession C105 , as evaluated by symptom observation in our previous work, appeared to be controlled by the single dominant gene Cys (19). It is possible then that the $\mathrm{C}-105$ resistance to CYSDV that we have shown here to be characterized by restricted virus movement is genetically controlled by Cys. However, the situation may be more complex. As mentioned before, grafted C-105 scions contained detectable amounts of CYSDV, they sustain replication and limited vascular movement of the virus, but they never showed any symptom of CYSDV infection. Therefore, the grafting experiments allowed us to reveal a tolerance that was masked in $\mathrm{C}$ 105 by its resistance to CYSDV upon whitefly inoculation. This parallels a situation described for another whitefly-transmitted virus, Tomato yellow leaf curl virus (TYLCV), a member of the genus Geminivirus (28). In this case, a hybrid between resistant wild tomato accessions showed resistance to virus infections and, additionally, tolerance to TYLCV-induced disease. Resistance could be overcome by graft inoculation, whereas tolerance could not, and genetic analyses showed that resistance and tolerance were under different genetic control (35). In the CYSDV case, we do not know whether tolerance and resistance to virus infection
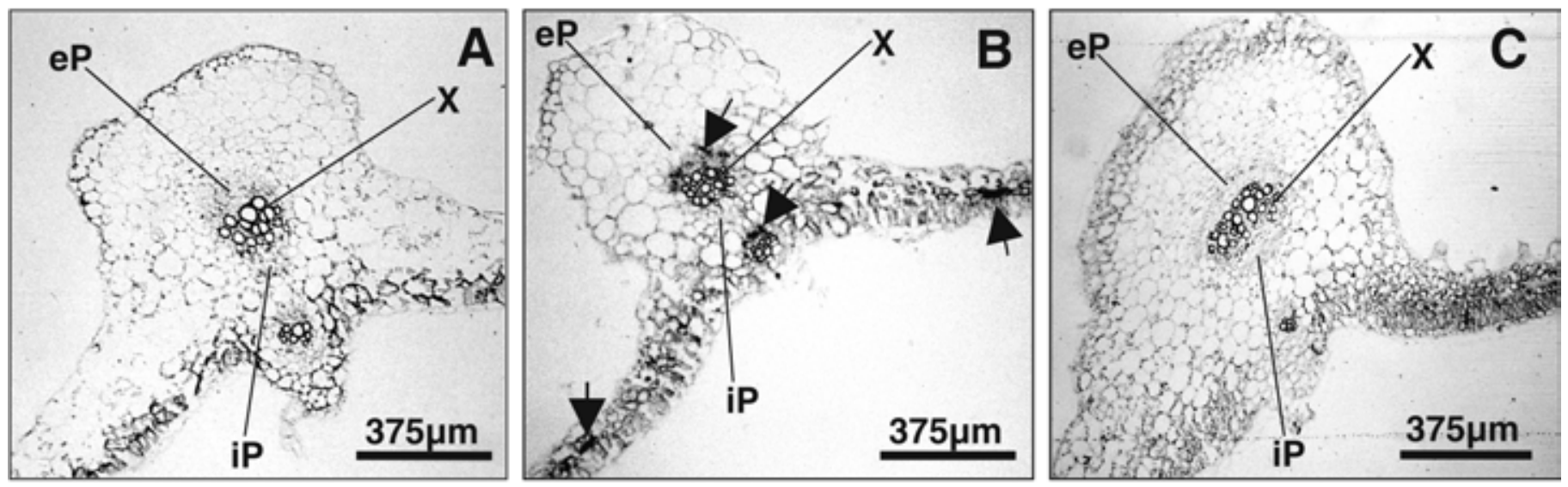

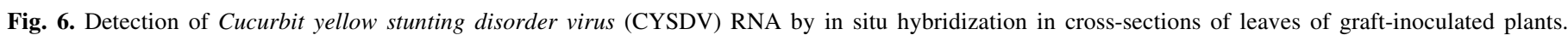

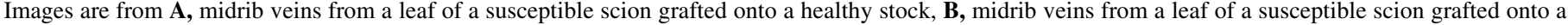

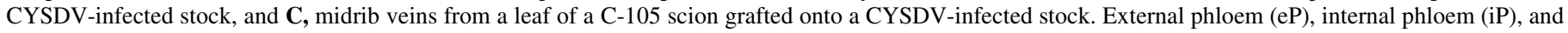

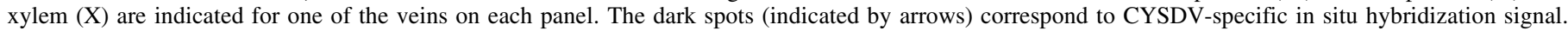
Magnification bars are shown. 
are under the same or different genetic control. It is possible that the observed overall low level of CYSDV multiplication in C-105 is not enough to trigger the cascade of events associated with symptom induction (24). In fact, lack of symptom expression has been shown to be accompanied by reduced levels of virus multiplication in other cases (5). Presently, we are carrying out a genetic dissection of the resistance which has the potential to provide interesting information regarding this aspect. It is important to ascertain the genetic control of the resistance and, in addition, to know whether or not the resistance is active against other virus strains $(30,31)$.

Introgression into commercial cultivars of the resistance to CYSDV that we have characterized would be particularly interesting due to the relevance of CYSDV-induced diseases. Against its use, it could be argued that resistance seems to be partial (i.e., virus could be detected in whitefly-inoculated leaves), and if a widespread field release occurs, selection could favor resistancebreaking strains that might become rapidly prevalent in CYSDV populations. There are cases of partial resistances that were overcome soon after release (e.g., the tomato resistance to Tomato mosaic virus controlled by the Tm-1 gene from Lycopersicon peruvianum; 29), but in other cases, partial resistances have been durable (e.g., the Pisum sativum resistance to Pea enation mosaic virus controlled by the En gene; 33). Probably, in addition to the type of expression of the resistance, several epidemiological and evolutionary factors are involved in the determination of resistance durability. It has been proposed recently that the evolutionary potential of cellular plant pathogens is a major determinant of the durability of resistance $(25,26)$. If this were the case for plant viruses, then the durability of the resistance that we have characterized would depend on parameters like the effective CYSDV population size, gene and genotype flow between CYSDV populations, and the frequency of genetic exchange between CYSDV individuals $(25,26)$. To our knowledge, very little information is available on these aspects of the CYSDV biology. Currently, we are studying the genetic variability of natural CYSDV populations in order to obtain information on these matters.

\section{ACKNOWLEDGMENTS}

This work was partly financed by Seminis Ibérica, S.A., through a subsidy of the "Fomento de Tecnología Industrial" program (Ministerio de Industria y Energía, Spain). J. M. Aguilar was the recipient of a "Formación y Especialización en Líneas de Interés para el Sector Industrial" fellowship of the Consejo Superior de Investigaciones Científicas (Spain). We thank E. Moriones and Y. Hernando for critical review of the manuscript and M. Victoria Martin for technical assistance.

\section{LITERATURE CITED}

1. Abou-Jawdah, Y., Sobh, H., Fayad, A., Lecoq, H., Delecolle, B., and Trad-Ferre, J. 2000. Cucurbit yellow stunting disorder virus-A new threat to cucurbits in Lebanon. J. Plant Pathol. 82:55-60.

2. Aranda, M. A., Escaler, M., Wang, D., and Maule, A. J. 1996. Induction of HSP70 and polyubiquitin expression associated with plant virus replication. Proc. Natl. Acad. Sci. USA 93:15289-15293.

3. Célix, A., López-Sesé, A., Almarza, N., Gómez-Guillamón, M. L., and Rodríguez-Cerezo, E. 1996. Characterization of Cucurbit yellow stunting disorder virus, a Bemisia tabaci-transmitted closterovirus. Phytopathology 86:1370-1376.

4. Desbiez, C., Lecoq, H., Aboulama, S., and Peterschmitt, M. 2000. First report of Cucurbit yellow stunting disorder virus in Morocco. Plant Dis. 84:596.

5. Fraser, R. S. S. 1990. The genetics of resistance to plant viruses. Annu. Rev. Phytopathol. 28:179-200.

6. Golecki, B., Schulz, A., and Thompson, G. A. 1999. Translocation of structural P proteins in the phloem. Plant Cell 11:127-140.

7. Guirao, P., Beitia, F., and Cenis, J. L. 1997. Biotype determination of Spanish populations of Bemisia tabaci (Homoptera: Aleyrodidae). Bull. Entomol. Res. 87:587-593.

8. Hämäläinen, J. H., Kekarainen, T., Gebhardt, C., Watanabe, K. N., and Valkonen, J. P. T. 2000. Recessive and dominant genes interfere with the vascular transport of Potato virus $A$ in diploid potatoes. Mol. PlantMicrobe Interact. 13:402-412.

9. Hassan, A. A., and Duffus, J. E. 1991. A review of a yellowing and stunting disorder of cucurbits in the United Arab Emirates. Emir. J. Agric. Sci. 2:1-16.

10. Hull, R. 2002. Mathew's Plant Virology. Academic Press, San Diego, CA.

11. Jackson, D. 1991. In situ hybridization in plants. Pages 163-174 in: Molecular Plant Pathology: A Practical Approach. S. J. Gurr, M. J. McPherson, and D. J. Bowles, eds. IRL Press, Oxford, WA.

12. Kao, J., Jia, L., Tian, T., Rubio, L., and Falk, B. W. 2000. First report of Cucurbit yellow stunting disorder virus (Genus Crinivirus) in North America. Plant Dis. 84:101.

13. Karasev, A. V. 2000. Genetic diversity and evolution of closteroviruses. Annu. Rev. Phytopathol. 38:293-324.

14. Kempers, R., Prior, D. A. M., van Bel, A. J. E., and Oparka, K. J. 1993. Plasmodesmata between sieve element and companion cell of extrafascicular stem phloem of Cucurbita maxima permit passage of 3-kDa fluorescent probes. Plant J. 4:567-575.

15. Kreuze, J. F., Savenkov, E. I., and Valkonen, J. P. T. 2002. Complete genome sequence and analyses of the subgenomic RNAs of Sweet potato chlorotic stunt virus reveal several new features for the genus Crinivirus. J. Virol. 76:9260-9270.

16. Lartey, R. T., Ghoshroy, S., and Citovsky, V. 1998. Identification of an Arabidopsis thaliana mutation ( $\mathrm{vsml}$ ) that restricts systemic movement of tobamoviruses. Mol. Plant-Microbe Interact. 11:706-709.

17. Liu, H.-Y., Wisler, G. C., and Duffus, J. E. 2000. Particle lengths of whitefly-transmitted criniviruses. Plant Dis. 84:803-805.

18. Livieratos, I. C., and Coutts, R. H. A. 2002. Nucleotide sequence and phylogenetic analysis of Cucurbit yellow stunting disorder virus RNA2. Virus Genes 24:225-230.

19. López-Sesé, A. I., and Gómez-Guillamón, M. L. 2000. Resistance to Cucurbit yellowing stunting disorder virus (CYSDV) in Cucumis melo L. Hortscience 35:110-113.

20. Louro, D., Vaira, A. M., Accotto, G. P., and Nolasco, G. 2000. Cucurbit yellow stunting disorder virus (genus Crinivirus) associated with the yellowing disease of cucurbit crops in Portugal. Plant Dis. 84:1156.

21. Mahajan, S. K., Chisholm, S. T., Whitham, S. A, and Carrington, J. C. 1998. Identification and characterization of a locus (RTM1) that restricts long-distance movement of tobacco etch virus in Arabidopsis thaliana. Plant J. 14:177-186.

22. Martelli, G. P., Agranovsky, A. A., Bar-Joseph, M., Boscia, D., Candresse, T., Coutts, R. H. A., Dolja, V. V., Duffus, J. E., Falk, B. W., Gonsalves, D., Jelkmann, W., Karasev, A. V., Minafra, A., Murant, A., Namba, S., Niblett, C. L., Vetten, H. J., and Yoshikawa, N. 2000. Family Closteroviridae. Pages 943-952 in: Virus Taxonomy. Seventh Report of the International Committee on Taxonomy of Viruses. M. H. V. Van Regenmortel, C. M. Fauquet, D. H. L. Bishop, E. Carstens, M. K. Estes, S. M. Lemon, J. Maniloff, M. A. Mayo, D. J. McGeoch, C. R. Pringle, and R. B. Wickner, eds. Academic Press, San Diego, CA.

23. Mas, P., and Pallas, V. 1995. Nonisotopic tissue-printing hybridization-A new technique to study long-distance plant-virus movement. J. Virol. Methods 52:317-326.

24. Maule, A. J., Escaler, M., and Aranda, M. A. 2000. Programmed responses to virus replication in plants. Mol. Plant Pathol. 1:9-15.

25. McDonald, B. A., and Linde, C. 2002. Pathogen population genetics, evolutionary potential, and durable resistance. Annu. Rev. Phytopathol. 40:349-379.

26. McDonald, B. A., and Linde, C. 2002. Pathogen population genetics and the durability of resistance. Euphytica 124:163-180.

27. Monis, J., and Bestwick, R. K. 1996. Detection and localization of grapevine leafroll associated closteroviruses in greenhouse and tissue culture grown plants. Am. J. Enol. Vitic. 47:199-205.

28. Moriones, E., and Navas-Castillo, J. 2000. Tomato yellow leaf curl virus, an emerging virus complex causing epidemics worldwide. Virus Res. 71:123-134.

29. Pelham, J., Fletcher, J. T., and Hawkings, J. H. 1970. The establishment of a new strain of tobacco mosaic virus resulting from the use of resistant varieties of tomato. Ann. Appl. Biol. 65:293-297.

30. Rubio, L., Abou-Jawdah, Y., Lin, H.-X., and Falk, B. W. 2001. Geographically distant isolates of the crinivirus Cucurbit yellow stunting disorder virus show very low genetic diversity in the coat protein gene. J. Gen. Virol. 82:929-933.

31. Rubio, L., Soong J., Kao, J., and Falk, B. W. 1999. Geographic distribution and molecular variation of isolates of three whitefly-borne closteroviruses of cucurbits: Lettuce infectious yellows virus, Cucurbit yellow stunting disorder virus, and Beet pseudo-yellows virus. Phytopathology 89:707-711.

32. Sambrook, J., and Russell, D. W. 2001. Molecular Cloning: A 
Laboratory Manual. 3rd ed. Cold Spring Harbor Laboratory, Cold Spring Harbor, NY.

33. Schroeder, W. T., and Barton, D. W. 1958. The nature and inheritance of resistance to the pea enation mosaic virus in garden pea, Pisum sativum L. Phytopathology 48:628-632.

34. Sokal, R. R., and Rohlf, F. J. 1995. Biometry: The Principles and Practice of Statistics in Biological Research. 3rd ed. W. H. Freeman \& Co., New York.
35. Vidavsky, F., and Czosnek, H. 1998. Tomato breeding lines resistant and tolerant to Tomato yellow leaf curl virus issued from Lycopersicon hirsutum. Phytopathology 88:910-914.

36. Wang, D., and Maule, A. J. 1995. Inhibition of host gene-expression associated with plant-virus replication. Science 267:229-231.

37. Wisler, G. C., Duffus, J. E., Liu, H.-Y., and Li, R. H. 1998. Ecology and epidemiology of whitefly-transmitted Closteroviruses. Plant Dis. 82:270280. 